\title{
LAS CRÓNICAS DE MANUEL PUIG EN SIETE DÍAS ILUSTRADOS: DESDE EL LUGAR DE LOS TEXTOS A LA IMPOSICIÓN DE UN CUERPO ${ }^{1}$
}

\author{
The Manuel Puig's Chronicles in Siete Días Ilustrados: from the place of \\ texts to the imposition of a body
}

Giselle Carolina Rodas ${ }^{2}$

\begin{abstract}
RESUMEN
En el verano de 1970, la revista semanal Siete Días Ilustrados publica una serie de ocho crónicas firmadas por el escritor Manuel Puig. El conjunto aparece durante la temporada que se inicia el 19 de enero y finaliza el 15 de marzo. En este artículo, nos detendremos en sus particularidades en tanto crónicas y, a partir de uno de los supuestos de la bibliografía material, que establece que las formas afectan al sentido, analizaremos los modos y medios de su puesta en página y de su circulación para concentrarnos luego en los textos y en la voz que se manifiesta en ellos.
\end{abstract}

Palabras clave: Manuel Puig, crónicas, Siete Días Ilustrados, textos, voz.

\begin{abstract}
In summer of 1970, the weekly magazine Siete Días Ilustrados publishes a series of eight chronicles signed by the writer Manuel Puig. The set appears during the season that begins on January 19 and ends on March 15. In this article, we will focus on some particularities of the texts as chronic and from one of the assumptions of the material bibliography, which establishes that the forms affect the sense, we will analyze the ways and means of its publication and its circulation for then concentrate on the textual analysis and the voice that is manifested in these chronicles.
\end{abstract}

Key Words: Manuel Puig, chronicles, Siete Días Ilustrados, texts, voice.

\footnotetext{
${ }^{1}$ Los primeros avances de este trabajo fueron presentados en el III Congreso Internacional Cuestiones Críticas, Facultad de Humanidades y Artes (Universidad Nacional de Rosario) en abril de 2013 con la comunicación "Chimentocriticorrespondencia: notas complementarias a las crónicas de Manuel Puig en Siete Días Ilustrados" y en las VIII Jornadas Internacionales de Filología y Lingüística y II Jornadas de Crítica Genética "Las lenguas del archivo", Facultad de Humanidades y Ciencias de la Educación (Universidad Nacional de La Plata) en junio de 2017 con la comunicación "Texto y contexto: las crónicas de Manuel Puig en Siete Días Ilustrados". Dedico estas investigaciones a Carlos Puig y Mara Puig, familia del escritor, por la amabilidad de siempre y a mis directoras, Dra. María Mercedes Rodríguez Temperley y Dra. Laura Juárez, por su guía.

2 Universidad Nacional de Lomas de Zamora. Docente de Literatura Española III. Argentina.

Correo electrónico: rodasgisellec@yahoo.com.ar
}

Recepción: 04-04-2017. Aceptación: 09-04-2018. 


\section{Inicios de un escritor cronista}

En 1969, Manuel Puig publica Boquitas Pintadas, una novela que rápidamente se convierte en un best seller de interés tanto para el público común como para la crítica especializada. Esto se produce casi al mismo tiempo que el escritor comienza a ser considerado en el exterior, cuando el diario francés Le Monde selecciona su primera obra, La traición de Rita Hayworth (1968), como una de las mejores del período 1968-1969. Poco después es convocado por el semanario Siete Días Ilustrados, donde colabora durante el verano de 1970 con un total de ocho crónicas tituladas "Cartas de Manuel Puig"3 en las que relata sus experiencias de viaje por las ciudades de Nueva York, Londres, París y Roma. ${ }^{4}$ En ellas, su voz se presenta como la de un cronista de espectáculos concentrado especialmente en temas de teatro y de cine. Se dedica a reseñar obras como "Cocó Chanel” (142), “Oh, Calcuta” (143), "Hair” (143) o "La tragedia del vengador" (144) y a glosar películas, como "El arreglo" de Elia Kazan (141). También se detiene en la biografía de algunos artistas que admira, como Katharine Hepburn (142) o Ginger Rogers (145) y en la obra de directores cinematográficos, como François Truffaut o Eric Rohmer (146). Además de esos tópicos, aunque en menor medida, pone atención en la moda, el clima, la vida cotidiana y las costumbres de las ciudades que visita tomando como objeto de su análisis cuestiones tan comunes como la inflación o los programas de televisión, y tan propias de la época como la influencia del movimiento contracultural hippie en Nueva York o los intereses de los jóvenes en Londres.

En 1993, los artículos publicados inicialmente en Siete Días Ilustrados fueron recopilados en una edición póstuma titulada Estertores de una década, Nueva York '78, ${ }^{5}$ cuya factura estuvo a cargo de la casa Seix Barral, encargada de reeditar la casi totalidad de la obra de Puig en los años noventa. El libro, estructurado en dos secciones, se inicia

\footnotetext{
${ }^{3}$ La serie corresponde a los números que van del 141 al 148 de la revista (19 de enero al 15 de marzo de 1970). Se citarán las crónicas de acuerdo con el número en que fueron publicadas.

${ }^{4}$ Para el momento en que se ponen en circulación los textos de Puig en Siete Días Ilustrados, ya existía una larga tradición de escritores que habían publicado crónicas en la prensa periódica de la Argentina. Entre ellos, quienes lo hicieron para La Nación, como José Ingenieros, que escribe sus crónicas desde distintos puntos de Europa (entre 1905 y 1906), José Martí, que lo hace desde Nueva York (1881-1891), Rubén Darío, especialmente desde Barcelona, Madrid y París (1892-1916), Roberto Payró, que publica sobre todo desde Bélgica (1907-1922), o Manuel Mujica Lainez, que lo hace entre 1935 y 1977 desde los más diversos lugares -Bolivia, China, Alemania, Gran Bretaña, Suecia, España, Perú (1935-1977). Asimismo, se pueden señalar los casos de José Enrique Rodó y de Oliverio Girondo, quienes trabajaron el género en Caras y Caretas (1917), o de Enrique González (ca. fines del '30 hasta 1943) y Roberto Arlt (1937-1942), que formaron parte del cuerpo de redacción de El Mundo, por solo mencionar algunos casos de cronistas emblemáticos vinculados con la escritura literaria.

${ }^{5}$ La publicación no menciona al editor responsable. Solo aparece una nota a su cargo donde se aclara la procedencia de los textos recopilados: "Estertores de una década, Nueva York '78, de Bazaar y Bye-Bye, Babilonia de Siete Días Ilustrados" (1993, p. 3). Este libro fue reeditado por el sello Booket de Buenos Aires en 2013.
} 
con "Estertores de una década, Nueva York '78" y presenta las crónicas que Puig había publicado en la revista española Bazaar hacia fines de 1978 y principios de 1979. Luego le sigue el apartado titulado "Bye-Bye, Babilonia", que reúne las crónicas divulgadas en el semanario argentino. Como se enuncia, la compilación en libro agrupa los textos en un orden inverso al de su aparición original, sin una razón que lo justifique, y es ambigua en cuanto a la datación de los textos de Siete Días Ilustrados, que han sido fechados en el “verano de 1969 / 1970” (1993, p. 3), aunque solo aparecen durante el último año. ${ }^{6}$

El libro también recoge algunas notables diferencias con respecto a la publicación en revista, no solo por ser un soporte material distinto, que en su diseño de página prescinde de elementos intrínsecos al objeto revista (como focalizadores, destacados, fotografías o epígrafes), sino también por algunas decisiones editoriales que resignifican su lectura. Basta para comprobarlo, cotejar algunas cuestiones referidas al paratexto. En el semanario, cada una de las "Cartas de Manuel Puig" está conformada por un total de entre dos y cuatro secciones reconocibles por estar precedidas por algún subtítulo ("Una revolución en las costumbres" [141, p. 14], “Argentinos en Nueva York" [143, p. 72], “Lombard, Lombardo" [143, p. 72] o "Los espectáculos turbios" [143, p. 72]), aunque algunas partes no cuentan con ellos. Esas zonas textuales establecen una relación sistemática y significativa, ya sea por los temas que tratan o porque comparten un mismo espacio urbano de referencia, manteniendo constantes envíos y reenvíos que cohesionan el conjunto. En el libro, esas secciones han sido dispuestas como apartados individualizados conformando una seguidilla de textos. El criterio adoptado no explicita la fecha de publicación de los segmentos, ni aclara la ciudad a la que se refieren, por lo que resulta difícil comprender cuáles formaban parte del mismo número de la revista, un dato significativo para su lectura. Se observan además algunos añadidos no declarados o justificados, por ejemplo, subtítulos que son agregados por el editor en las secciones que prescindían de ellos con la finalidad de homogeneizar la seguidilla de textos titulándolos a todos. Es lo que sucede con "Good morning, Nueva York" (1993, p. 63), "London, London” (1993, p. 100) o "La pérfida Albión” (1993, p. 110), así como también con el título que reúne al conjunto, "Bye-Bye, Babilonia". Estas operaciones dan como resultado textos con una mayor independencia entre sí, que acentúan la forma del relato, debido a

\footnotetext{
${ }^{6}$ En el libro de 1993, también se omite la mención de las crónicas romanas cuando se las presenta en la portada y en la portadilla (“crónicas de Nueva York, Londres y París publicadas en Siete Días Ilustrados" [1993, pp. 1-3]), a pesar de que los textos aparecen incluidos en el interior del volumen.
} 
que se concentran casi exclusivamente en la narración y, por ende, en el aspecto literario de las crónicas.

Como es sabido, la crónica, género “de fronteras abiertas” (Bernabé, 2006, p. 7), se reconoce por ser un punto de encuentro entre elementos factuales y estéticos que responden a la convivencia del discurso literario con el de la prensa. De acuerdo con Susana Rotker (2005, p. 130), un aspecto medular de la cronística es también su alta referencialidad y actualidad. ${ }^{7}$ Es frecuente que en el traspaso de las revistas al formato libro, estos textos experimenten un proceso de disminución de los rasgos periodísticos y un acrecentamiento de los literarios, gracias a la desactualización producida en los dispositivos contextuales que suelen actuar como guías de lectura (Rotker, 2005, p. 100; Laera, 2007, pp. 29-30). ${ }^{8}$ Así y todo, para el caso que expusimos, estas razones no obstan para valorar la publicación en libro, debido al poder de divulgación de unos textos que, de otro modo, resultarían de muy difícil o de nulo acceso. De hecho, la principal crítica literaria referida al tema analiza el corpus a través de su compilación en ese formato (Páez, 1995; Bocchino, 2006; Idez, 2009).

Consideramos que las crónicas de Siete Días representan un espacio en el cual Puig se asume como escritor profesional con una poética y una voz propias, y con un estilo tendiente a la experimentación sobre la lengua. Siguiendo entonces la idea de que texto y contexto son un tejido común que resemantiza (van Dijk, 1998, p. 93), este trabajo propone un doble objetivo. Por un lado, estudiar las crónicas publicadas en el entorno de la revista Siete Días Ilustrados para concentrarse en elementos que permitirán poner estos textos, y sus medios, en sistema con otros de corte similar con la finalidad de extraer conclusiones sobre la producción del autor y el modo en que esta se acomoda e instala en el campo literario argentino de los años 70, e indicar coordenadas sobre la autofiguración y la imagen de escritor que, en cierto sentido, el mismo Puig se esforzó por construir. Por otro lado, en una segunda sección, el interés estará puesto en estudiar los puntos de articulación y construcción de los textos en sí mismos, en los que pueden reconocerse

\footnotetext{
${ }^{7}$ Rotker dice que "el criterio de factualidad no debe incluir ni excluir a la crónica de la literatura o del periodismo. Lo que sí era y es un requisito de la crónica es su alta referencialidad -aunque esté expresada por un sujeto literario-y la temporalidad (la actualidad)" (2005, p. 130).

${ }^{8}$ Para Rotker "es necesario incluso recordar textos modernistas que, de ser publicados primero en los diarios, pasaron a ser leídos como cuentos, despojados luego del elemento actualidad; es el caso de los Cuentos frágiles y Cuentos de color humo de Gutiérrez Nájera, 'Ésta era una reina', ‘A poblá!', 'Bouquet' o 'El año que viene siempre es azul', de Rubén Darío. Lo mismo se puede decir de textos como 'El terremoto de Charleston' o 'Jesse James' de José Martí” (2005, p. 100).
} 
elementos tan significativos como las intenciones del autor y la focalización de su mirada y su voz en tanto cronista para indagar qué mira y cómo lo hace, de qué manera enuncia y cuál es la retórica y el estilo de su palabra.

\section{El lugar de la crónica}

\subsection{Zona de publicación: Siete Días Ilustrados}

La bibliografía material, disciplina que estudia los textos como formas registradas, así como los procesos de su transmisión, incluyendo su producción y recepción (McKenzie, 2005, p. 30), enseña que el modo de publicación incide en el sentido de lo escrito. El papel, la tipografía, las ilustraciones y la encuadernación son considerados fuentes que informan sobre el texto y su transmisión (Bowers, 1949; Gaskell, 1999; Laufer, 1972). En el caso particular de los escritos impresos, tanto el formato como la mise en page, las secciones, las convenciones tipográficas y la forma de puntuar están investidos de función expresiva (McKenzie, 2005). Este marco permite considerar el análisis del medio de publicación y de la puesta en página como fuentes de información contextual en las crónicas que se analizan.

La revista Siete Días Ilustrados nace en 1965 cuando la editorial Abril y el diario La Razón de Buenos Aires se asocian para crear un suplemento que se incluía dentro del periódico al mismo precio. En 1967, el semanario se independiza y se convierte en una publicación exclusiva de la editorial. En Paren las rotativas, Carlos Ulanovsky (2005b, p. 262) señala que cuando Siete Días Ilustrados deja de ser un suplemento de La Razón pasa a ser dirigido inicialmente por Luis Clur ${ }^{9}$ y luego por Norberto Firpo, ${ }^{10}$ quien venía de Primera Plana, un semanario dedicado al análisis político y cultural de gran influencia en la Argentina de entonces. ${ }^{11}$ Bajo el liderazgo de Firpo se agruparían en la redacción de

\footnotetext{
${ }^{9}$ Luis Clur (1922-2004) fue un periodista de larga trayectoria. Trabajó como redactor de noticias en Radio El Mundo y como secretario de redacción en los influyentes periódicos Clarín, La Nación y La Opinión.

${ }^{10}$ Norberto Firpo (1931-2017) trabajó desde 1980 para La Nación, donde desarrolló una larga carrera. También se dedicó a la escritura literaria con la publicación de cuentos y novelas como Cuerpo a Tierra, Grandísimo idiota y Redondeces.

${ }^{11}$ Primera Plana fue fundado en 1962 por Jacobo Timerman, quien se desempeñó en la dirección hasta mediados de 1964. Luego, el mismo grupo de trabajo que había sido reunido por Timerman pasó a ser tutelado por Victorio Dalle Nogare hasta el 5 de agosto de 1969, cuando la revista es clausurada por la dictadura militar de Juan Carlos Onganía. Primera Plana reapareció con su nombre original el 8 de septiembre de 1970 y se extendió hasta 1973. Para entonces, el equipo de profesionales reunidos originalmente se había desmembrado.
} 
Siete Días jóvenes valiosos en busca de un perfil innovador, entre ellos, los escritores Germán Rozenmacher y José Tcherkaski.

La publicación estaba orientada a la información de interés general. Actualidad, política, hechos resonantes y personajes famosos formaban parte de sus contenidos y la ubicaban en la misma línea que otras de corte similar, como Gente y la actualidad o Semana Gráfica (Ulanovsky, 2005a , p. 16). La heterogeneidad de las notas que caracterizaba a ese tipo de publicaciones, oscilante entre las de tono solemne y las de carácter trivial, tenía por finalidad captar un público amplio y masivo. Basta echar un vistazo a la diversidad temática que se anuncia en sus portadas. En el número 141 de la revista (semana del 19 al 25 de enero de 1970), donde Puig publica la primera de sus crónicas, se leen titulares como "Fiesta en el Lido de París", que anuncia una nota sobre la inauguración de la temporada de ese teatro de revistas parisino; "Rusia según Arthur Miller", que adelanta un libro donde el dramaturgo relata sus experiencias en la Unión Soviética y "El divorcio en la Argentina", que informa sobre los obstáculos para concretar el divorcio a pesar de que la ley ya había sido sancionada. Ese tipo de portada, o puertas signo (Cingolani, 2009), se desarrolla especialmente durante los años 60 y se caracteriza por introducir signos lingüísticos y visuales anticipando lo que se encontrará en el interior de la revista, como puede verse en Siete Días Ilustrados.

De acuerdo con Lucía Ulanovsky, las revistas semanales, y en reservada medida los diarios de los años 60 y 70, adoptaron estilos que hasta entonces habían sido poco frecuentes: "notas firmadas, artículos de la vida cotidiana, relevancia de la sección cine y teatros" (2009, p. 2). Otro aspecto que también se destacaba en esos semanarios era el espacio concedido a las fotografías. Siete Días Ilustrados les dio una prioridad que permitía situarla en la perspectiva de la publicación americana Life, donde las imágenes se insertaban en una diagramación dinámica con el doble objetivo de atraer y vehiculizar la opinión pública y de movilizar las emociones y sensaciones del lector (Ulanovsky, 2009, p. 3). ${ }^{12}$ Esto se observa también en las tapas del corpus que se analiza, donde se reproducen estampas a plana entera y en colores para captar la atención del potencial lector. El formato de la revista, de dimensiones generosas $(350 \times 265 \mathrm{~mm})$, es apropiado

\footnotetext{
12 Mario Ceretti, que se desempeñaba desde los servicios exteriores en Surameris Noticias, lo testimonia: "una revista que, a la manera de Life, contaba historias con fuerte acento humano y apelaba a fotografías muy grandes" (Ulanovsky, 2005b, p. 263).
} 
para acentuar el impacto visual, ya que en los kioscos de diarios raramente podía pasar desapercibida. ${ }^{13}$

Este medio de publicación, especializado en temas de actualidad y variedades, que pone en circulación y al alcance del público las crónicas de Puig, puede pensarse en relación con otros espacios de circulación masiva que colaboraron por aquel entonces a la proyección y consagración del escritor. En la tapa doble del número dedicado a "Las figuras del año '69" de la revista Gente (1970), evento del que solían participar modelos, científicos, políticos, futbolistas, escritores y cantantes (Ulanovsky, 2005a , p. 233), Puig muestra su novela Boquitas pintadas posando junto a personalidades del espectáculo, como el actor Alberto Olmedo, la vedette Nélida Lobato y los conductores de televisión Roberto Galán y Héctor Larrea. Esto supone un notable poder de difusión considerando que la revista tenía una tirada de alrededor de 100000 ejemplares por número. De manera similar, el escritor también se presenta fotografiado en el número cero de La Revista de los Jueves de Clarín (1971), donde se encuentra junto a reconocidas figuras del arte y del espectáculo nacional como la vedette Mimí Pons, los actores Federico Luppi y Dora Baret, el director de cine Manuel Antín y el artista plástico Antonio Berni, formando parte de una escena recreativa y distendida.

Su aparición en otras publicaciones de ese estilo también puede vincularse con la construcción de una imagen de escritor poco convencional. En una entrevista para la revista femenina Femirama (1973), puede verse fotografiado con polera blanca, pantalones ajustados a rayas y borceguíes de caña alta anudados hasta la rodilla. También es llamativa la decoración de su habitación: una alfombra atigrada, una silla de acrílico transparente $\mathrm{y}$, en las paredes, las fotos de las stars que captan la atención del entrevistador:

En su escritorio -sin muchos libros, lo que evidentemente no es muy promocional- languidecen, desde sus "posters", los velos y las arqueadas cejas de Marlene Dietrich y los ojos afroamericanos de Joan Crawford. Su dormitorio también se afina con otros amores y desvelos: Bette Davis, Jean Harlow y, en la cabecera de la cama, naturalmente, la "divina" Greta Garbo (Garsar, 1971, p. 40).

\footnotetext{
${ }^{13}$ El número 141, por ejemplo, presenta a una de las artistas del teatro de revistas parisino Lido de cuerpo entero, enfundada en un traje llamativo con plumas y brillos. Este tipo de representaciones que exhibe mujeres atractivas aparece recurrentemente en la cubierta, aunque en menor medida también se pueden ver otras dedicadas al deporte o a la política.
} 
La imagen que proyectan estas revistas contrasta con el típico retrato del intelectual posando sobre un fondo de biblioteca colmada de libros y se ajusta a la que el mismo Puig se esforzó por construir como un escritor que no venía de la literatura sino del cine (Sosnowski, 1973). ${ }^{14}$

\subsection{Crónicas de Manuel Puig en Siete Días Ilustrados: la mise en page}

El concepto de sintaxis de las revistas (Sarlo, 1990, p. 10), referido al conjunto de decisiones que señalan los rasgos de cada publicación y definen su coyuntura, se ajusta a los objetivos de este apartado donde se analiza la puesta en página de las crónicas. ${ }^{15}$ También la idea de que en las revistas es posible señalar dos espacios vinculados (Osuna, 1998, p. 11): el material, identificado con la superficie que mide, y el simbólico, identificable en otros signos como las ilustraciones, los ornamentos o los colores. Las crónicas de Puig ocupan un espacio notable en el despliegue de la doble página, en la información dispuesta a cuatro columnas, acompañada de imágenes y de otros elementos que les dan notoriedad.

En el diseño de las crónicas, un recuadro en la parte superior presenta el titular “Cartas de Manuel Puig" en tipografía de gran tamaño que destaca, con letra aún mayor, el nombre del autor, señal de su prestigio. Vale la pena detenerse en este punto en algunas cuestiones referidas al género epistolar, tema estudiado sobre estas crónicas particularmente por Ariel Idez (2009) ${ }^{16}$ como una escritura en tensión y recurrencia con el género cronístico y con el topos puiggeano del chisme, ${ }^{17}$ aunque también puede

\footnotetext{
${ }^{14}$ En la entrevista que le realiza Saúl Sosnowski (1973), dice Manuel: "Yo no vengo de ninguna tradición literaria. Vengo del cine; de oír radio, de ver folletines, melodramas de la Metro. Es posible que inconscientemente yo entre en alguna tradición literaria argentina. De lo que sí estoy consciente es de ciertos trucos narrativos aprendidos viendo cine" (1973, p. 73).

${ }^{15}$ Para Beatriz Sarlo: "La sintaxis de una revista es casi siempre el producto de juicios de valor tanto como la elección de los textos que se ordenarán según esa sintaxis. La política de una revista es un orden, una paginación, una forma de titular que, por lo menos idealmente, [sirve] para definir el campo de lo deseable y lo posible de un proyecto" (1990, p. 12).

${ }^{16}$ Idez pone en sistema estas cartas con las enviadas por Puig a su madre (compiladas por Goldchluk, 2005 y 2006): "La elección de este género no será inocente ni casual y es sumamente coherente con el modo en que Puig concibe la literatura: a través del choque y la reconciliación de opuestos" (2009). Un simple cotejo de las cartas a la familia y de las crónicas basta para poner en evidencia la cercanía del corpus. En la crónica del número 142 (semana del 26 de enero al 1. ${ }^{\circ}$ de febrero), expresa la sensación que le produce Katharine Hepburn cuando lo recibe en su camarín luego de interpretar a Cocó Chanel: "La cara gastadísima, nunca he visto una piel más irritada, parece inflamada, un gran sabañón. Los ojos son verde claros, siempre húmedos, súper sensibles" (142, p. 15). Esto puede ponerse en paralelo con la epístola del 31 de agosto de 1956 enviada a su madre donde relata un acontecimiento muy similar: "Personalmente [Marlene Dietrich] es un monstruo, para colmo está flaca escuálida, la cara es amarillo muerto y estaba sin maquillaje. Lo que no ha perdido es la voz maravillosa y la clase para hablar" (Puig, 2005, p. 33).

${ }^{17}$ Según Idez, "en estas crónicas una forma de comunicación vulgar (el chisme) se expone en la escena de un género íntimo (el epistolar) para vulnerar la lógica informativa y producir un conocimiento de otra índole, ajeno al periodismo
} 
pensarse en relación con las matrices del género como se verá a continuación. Se observan entonces algunos indicadores típicos de las circunstancias comunicativas (Bouvet 2006), con ciertos desplazamientos respecto al modo tradicional en que suelen presentarse en las cartas. Por ejemplo, la referencia al lugar de escritura, usualmente ubicada a la derecha de la hoja junto con la datación, se lee en el interior del recuadro mencionado hacia la izquierda, donde el topónimo adquiere un matiz formular: "desde Nueva York”, “desde París”, “desde Roma”, “desde Londres”. Se construye además una imagen del "otro" como destinatario a través de un enunciador cercano y familiar (Idez 2009) que apela al enunciatario mediante fórmulas con las que se compromete a seguir narrando determinados temas para conservar y acrecentar su interés: "volveré sobre el asunto", "les contaré otro día", "les contaré en la próxima con lujo de detalles", "en el próximo número sin falta" (141: 14-15). Al decir de Nora Bouvet (2006), la retórica del género suele imitar en la escritura la comunicación privada, personal u oral, aspecto sobre el que se pueden presentar numerosos ejemplos en estas cartas-crónicas como la introducción de la palabra ajena, ${ }^{18}$ el uso de formas coloquiales ${ }^{19}$ o la dramatización en los diálogos y la irrupción de lo subjetivo. ${ }^{20}$ Ese estilo puede ponerse en continuidad con el ensayado por el escritor en las novelas publicadas hasta entonces (La traición de Rita Hayworth [1968] y Boquitas pintadas [1969]), donde la oralidad fluye y desborda (Pauls 1986, Goloboff 1997, Giordano 2001), de modo que dentro de un género de no ficción, como lo son estas crónicas, se establece una prolongación coherente con la poética literaria que el escritor practica y modela como signos de su marca autoral y de una identidad literaria que se autoafirma.

\footnotetext{
y a la literatura aunque tome recursos de ambos" (2009). Sobre el tópico del chisme en Puig puede verse Pauls (1986). En el caso de las crónicas, varios de los chismes versan sobre las estrellas de cine o teatro en el set de filmación, tras bambalinas o en su vida cotidiana: "Crawford adora el frío y sus sets de filmación son proverbiales heladeras" (142, p. 14); "Hay quien dice que Astaire se quiso disfrazar de enfermera para robarle la escena [a Ginger Rogers], pero es sólo un rumor maligno" $(145$, p. 83$)$.

${ }^{18}$ Algunos ejemplos: “¿Será cierto entonces lo que me contó aquel argentino? De vuelta de San Francisco me había dicho que por la calle la gente (no necesariamente hippie) sonreía y dirigía la palabra a extraños" (141, p. 14); "El teléfono sigue costando 10 centavos de dólar (35 pesos argentinos, viejos por supuesto), pero me cuesta encontrar uno sin la tira amarilla: 'Perdón, temporariamente fuera de uso"" (141, p. 14); "Comentario del taximetrero que me lleva al hotel: 'La inflación cunde, después de casi 20 años de estabilidad de precios. Pero los salarios no se han movido mayormente"” (141, p. 14); "Cocó se enfada [...] y la protegida dice: 'Pero no será él quien mande, estaremos en un plano de igualdad'. Cocó responde: 'Eso para la mujer es bajar un escalón”” (142, p. 15).

${ }^{19}$ Algunos ejemplos de estos usos son: "éxito mersón" (141, p. 14), expresión que utiliza para descalificar con cierta moderación lo ordinaria y vulgar que le parece la película de James Bond, Al servicio de Su Majestad (Peter Hunt, 1969); "la ropa es colorinche" (141, p. 15), forma que refiere a la moda excesivamente colorida de los hippies; y "adefesio" para mencionar lo ridículo y disparatado que le parece el segundo cuadro de la obra de teatro "Cocó"(142, p. 15).

${ }^{20}$ Estos dos últimos aspectos serán desarrollados con detenimiento más adelante.
} 
En el mismo sentido, puede leerse la firma que se reproduce al pie de cada una de las cartas-crónicas. Como es sabido, la duplicación de una grafemia caligráfica es la manera que el discurso tipográfico se ingenia para consolidar la importancia del texto, pues lo que se pretende es retrotraer la lectura al acto mismo de la creación (Osuna, 1998, p. 89). La firma también es lo que convierte al redactor de un periódico o de una revista en un autor y conduce al lector a buscar en sus escritos un estilo reconocible, un tono, una temática común (Laera, 2007, p. 16), ${ }^{21}$ por lo cual es aquello que lo compromete y que lo identifica con su producción, como puede notarse en el autógrafo que permite leer con total claridad el nombre y el apellido del villeguense.

Otros modos de reproducir la singularidad autoral se presentan en el diseño de página, en el recuadro que se mencionaba anteriormente. Allí se actualiza la imagen del escritor en un retrato suyo en blanco y negro. Según Roland Barthes (2003), la fotografía adquiere sentido como depósito de elementos dotados de significación que pueden leerse tanto en aspectos técnicos -el tamaño de la imagen, el papel, la exposición o las lucescomo en la expresión gráfica de la emoción y de los gestos (2003, pp. 166-168). ${ }^{22}$ La imagen reproduce a Puig fumando un cigarrillo, absorto y en actitud reflexiva, de un modo más intelectual que el señalado en las revistas comentadas anteriormente, matizando aquella expresión.

Otras fotografías en blanco y negro, cuyas medidas oscilan entre los 80 x $60 \mathrm{~mm}$ y los 120 x $80 \mathrm{~mm}$, acompañan estos textos en conjuntos de tres o cuatro unidades por entrega. En coincidencia con las que solía reproducir Siete Días Ilustrados, resumen una escena y presentan imágenes curiosas y espectaculares que ilustran y redundan en los temas de las crónicas, los espectáculos y la vida cotidiana. Usualmente corresponden a retratos de actores y de actrices, ${ }^{23}$ de dramaturgos, escritores y cineastas, ${ }^{24}$ así como también de escenas de los espectáculos que se mencionan en los textos ${ }^{25}$ y situaciones de la vida citadina común. ${ }^{26}$ Los epígrafes que las acompañan en algunos casos dan alguna

\footnotetext{
${ }^{21}$ Esa signatura contrasta con la de los escritores modernistas a quienes se les tendía a borrar en tanto personalidades individualizadas "eliminando sus nombres al pie de sus escritos" (Rotker, 2005, p. 106).

${ }^{22}$ Barthes escribe: "La convención fotográfica en sí misma está, por otra parte, llena de signos. La exposición de frente acentúa el realismo del candidato, sobre todo si está provisto de anteojos escrutadores. En esta actitud, todo expresa penetración, gravedad, franqueza: el futuro diputado dirige la mirada al enemigo, al obstáculo, al 'problema"' (2003, p. 168).

${ }^{23}$ Ejemplos: Barbra Streisand (141, p. 14), Ginger Rogers (145, p. 83), Katharine Hepburn (142, pp. 14-15).

${ }^{24}$ Ejemplos: Elia Kazan (141, p. 14), Harold Pinter (145, p. 82), Witold Gombrowicz (147, p. 58).

25 Ejemplos: "Cocó Chanel" (142, p. 15), "Hair" (143, p. 72), "La tragedia del Vengador" (144, p. 70), "Troilo y Crésida" (145, p. 82).

${ }^{26}$ Por ejemplo, la referencia a la forma de vida de los hippies (141, p. 15).
} 
mínima pauta sobre los temas desarrollados en los cuerpos textuales ("Barbra, en Dolly: Sin arrugas" [141, p. 14], "Katharine \& Spencer: Juntitos" [142, p. 14], “Tragedia del vengador: emoción" [144, p. 70]), pero también subrayan el tono humorístico usual en la voz enunciadora. Es lo que sucede, por ejemplo, en el epígrafe de la fotografía de Faye Daneway y Kirk Douglas: "Faye y Kirk en película que salió cómica sin la menor intención” (N. ${ }^{\circ} 141$, p. 14), o en el de Elia Kazan (N. ${ }^{o}$ 141, p. 14): “Elia Kazan: ¡Que se reviente!”, en alusión a la anécdota que se relata en el cuerpo de la crónica:

Hace años, cuando Kazan presentó en teatro Después de la caída, de Arthur Miller, ordenó que el personaje inspirado cruelmente en Marilyn Monroe fuera vestido, peinado e interpretado como un calco de la actriz muerta hacía poco. Con intención totalmente destructiva. En aquel momento le deseé a Kazan que reventara (141, p. 14).

Otro espacio de la página donde se sintetizan los temas de estos textos se presenta como un destacado, a la derecha del recuadro superior. Los enunciados dispuestos en ese lugar suelen acentuar el tono desenfadado y el humor sarcástico: “¿Será cierto que la gente se ha vuelto dicharachera?" (141, p. 15), “ahora, negras y negros se dejan las motas largas" (141, p. 15), "Consecuencias de una pulmonía de Joan Crawford" (142, p. 15), "Pelos y señales de la noche del estreno de 'Cocó', comedia musical" (142, p. 15), como si el humor fuera una vía de escape frente a la uniformidad, a lo aburrido y a lo aplastante que por momentos señala la voz enunciadora, como se verá más adelante.

Los intertítulos y subtítulos que segmentan las distintas partes condensan y preanuncian el contenido del texto y, como es común en el discurso de la prensa, suelen ser llamativos o cautivantes (“Audacia en escena", "Una revolución en las costumbres", “Los dogmas del zar", “Coreógrafa que descubrió a Julie Andrews aspira al perdón de la humanidad"). Otras veces aparecen palabras-consignas (Idez, 2009) que abren cada párrafo y son disparadoras de temas. En algunas oportunidades intertítulos, subtítulos o palabras-consignas se encuentran en tipografía negrita, ${ }^{27}$ para establecer juegos verbales con las letras resaltadas. Por ejemplo, en la crónica de Londres (N. ${ }^{\circ}$ 144, pp. 70-71) despuntan las palabras "frío", "helado", "tibio", "caliente”, "me quemo" que sintetizan el estado ánimo del cronista en referencia a cada episodio que se cuenta o describe en el

\footnotetext{
${ }^{27}$ De acuerdo con la clasificación que propone Ariel Idez en su artículo (2009), se los puede identificar en aquellos que son descriptivos ("Homenaje a Von Sternberg", "Argentinos en Nueva York") y los que son explicativos ("Génesis del boom Katharine Hepburn", "Los espectáculos turbios"). Un tercer grupo que se identifica como toponímicos, corresponde en gran medida a los que introduce, sin dar cuenta de su intervención, el editor de Estertores de una década ("Good morning Nueva York"), como se anunciaba anteriormente.
} 
apartado. Ese juego, que se sirve de las tipografías para conferir otros sentidos, ya había sido practicado por el escritor en Boquitas pintadas, por ejemplo, en los episodios en que las letras cursivas representaban el fluir de conciencia de los personajes, como el de Mabel y Pancho en el capítulo diez o el de Celina y la viuda en el doce. Esto puede pensarse como un signo de que en sus crónicas Puig explota las técnicas de escritura practicadas hasta entonces y va más allá en la enunciación de una voz que se asume en una primera persona en la que el autor se deja ver por primera vez (Idez, 2009). La puesta en página extrema ese gesto porque como las cartas, que son "escritura del cuerpo, escritura hecha cuerpo" (Bouvet, 2006, p. 87), que no por azar toman en préstamo el vocabulario de la anatomía: “"cabeza', ‘cuerpo’ y 'pie’ de la carta”” (Bouvet, 2006, p. 87), las crónicas del villeguense dibujan ese mismo recorrido en un rostro visible en la foto que lo reproduce, en un torso materializado en el cuerpo textual y en un pie de firma reconocible por la mano que escribe su propio nombre.

\section{Textos de un escritor que se afirma}

\subsection{La mirada, la palabra y la voz}

Como se ha señalado, en sus crónicas Puig recorre en general los mismos temas y ronda en la misma categoría de personajes relacionados con lo artístico (Katharine Hepburn, Ginger Rogers, François Trauffaut, Witold Gombrowicz, Von Sternberg, Césare Zavattini). La impresión general de la ciudad parece entonces una excusa para hablar de otra cosa más concreta que concentra la mirada en reseñas, comentarios y biografías sobre sus artistas favoritos, como ocurre en la crónica del número 146, referida casi íntegramente a la trayectoria del director François Trauffaut. La voz del cronista marca semblanzas y desarrolla el itinerario profesional de sus personajes. Su ojo focaliza en la acción y los presenta actuando, bailando, cantando o en el set de filmación. Apunta sobre su forma de interpretar distintos roles, cómo se ven fuera de la pantalla, qué se dice de ellos, qué se sabe de su vida cotidiana o cómo les ha afectado el paso del tiempo. Por ejemplo, atiende a la figura de Katharine Hepburn y le dedica casi íntegramente el espacio del número 142 esbozando su amplia trayectoria. Para hacerlo, comienza más allá de sus orígenes, situándose en una escena que tiene por protagonista a Joan Crawford y en el inoportuno resfrío que lleva a Katharine a reemplazarla para comenzar a ascender en su 
carrera y crecer en fama. Un trazado que deriva en la puesta en paralelo con la vida del personaje que Hepburn interpreta en ese momento en teatro: Cocó Chanel. Y si la performance de Katharine no convence totalmente al crítico, en una obra que a su criterio no le permite lucirse, ${ }^{28}$ el esbozo de la trayectoria cinematográfica es lo que compensa la justicia poética para una actriz que el público ama:

¿No tengo nada bueno para decir sobre Cocó? Pocos aplausos durante la matinée, pero al parecer K. H. para el saludo final el público explota en una ovación, y se produce lo nunca visto en Broadway, la concurrencia íntegra se pone de pie para aplaudir a K. H., a la viuda de Spencer Tracy, a la solterona de Locura de verano, a la suegra blanca de Sidney Poitier. Es una historia de amor entre público y actriz, cuatro décadas de romance (142, p. 15).

Estos trazados se complementan con la exposición de concepciones más teóricas en una voz que muta en la forma del ensayo. Es lo que ocurre cuando se dedica a Cesare Zavattini (148) quien, además de ser uno de los guionistas clave del neorrealismo italiano, fue director del Centro Sperimentale di Cinematografia de Roma durante los años 50, época en que el joven Puig había concurrido como estudiante de dirección. Ya desde aquella temporada, el escritor argentino se mostraba discordante con la concepción del arte cinematográfico que impulsaba el italiano. ${ }^{29}$ Frente a la espectacularidad del cine de los años dorados de Hollywood, que tanto había conmovido a Manuel desde su infancia, y que siempre lo fascinaría, el neorrealismo propugnaba todo lo que el villeguense rechazaba: el recorrido de la realidad, los tiempos detenidos, la visión objetivista, las acciones cotidianas. ${ }^{30}$

No es menor en este punto señalar la importancia que el tiempo adquiere en estas crónicas en una voz que construye un sistema de oposiciones constantes entre el tiempo próspero "que fue" y el tedio de "lo que es" a través del refuerzo semántico de la comparación. El pasado y el presente articulan el momento de la experiencia de lo ya

\footnotetext{
${ }^{28}$ Dice Puig: "Cocó se siente algo abatida, toma champagne, y aquí por primera vez se empieza a desprender la magia de la gran Katharine que conocemos. Sola en el escenario, con otro matiz en su voz, susurrando apenas, llama al padre muerto y le dice que está sola. Nos hiela la sangre a todos (...). Pero la orquesta ataca y ella empieza a cantar y el hechizo se quiebra, porque K. H. [Katharine Hepburn] no es cantante, y preocupada por no desentonar pierde tensión y todo al diablo otra vez" (142, p. 15).

${ }^{29}$ Dice Puig en el prólogo a La cara del villano y Recuerdo de Tijuana (1985): “[Zavattini y sus seguidores] ante todo querían y con toda razón, salir de las fórmulas hollywoodeanas para intentar un cine más inquieto intelectualmente. Un cine de denuncia social, instigador, inteligente. Pero esa operación los llevaba a un error grave: una de las características principales de Hollywood era el cuidado de la armazón narrativa, y dado que para esa nueva óptica crítica todo Hollywood era sinónimo de cine reaccionario, pues, saber narrar también resultaba un rasgo reaccionario" $(1985$, p. 8). ${ }^{30}$ Dice en la crónica romana: "Decretos principales del César: el cine de autor, que revelase una visión individual, quedaba abolido. La única fuente de inspiración posible era il pedinamento della realtá (el recorrido de la realidad). A su entender, todos los significados más sublimes brotaban con sólo fotografiar la realidad. No advertía, cesareando impío, que la realidad presenta formas exteriores (a veces engañadoras) e interiores (ocultas pero más significativas), y condenaba todo intento de recrear la realidad mediante una síntesis poética. Implaccabile" $(148$, p. 80).
} 
vivido frente a la actualidad de la crónica porque en este sistema vale la voz nostálgica que añora. Como ocurre cuando nota la falta de personalidad escénica de Ginger Rogers en teatro $(145)^{31}$ y rememora con melancolía y amor las imágenes de cine en que Ginger bailaba y se movía con encanto y fascinación: “¡Ginger! Idéntica a sí misma. Baila el gran número del primer acto con muda cautela, tiene 59 años. Pero levanta la pierna muy alto. Qué difícil criticarla: se unen la decepción a la nostalgia y al cariño" (145, p. 82). Esto mismo sucede en el contraste que establece con cuestiones de la vida común, por ejemplo, en la crónica de New York, cuando repara en el costo de un boleto desde el aeropuerto al centro: "El boleto aeropuerto-centro costaba hasta hace dos años 1,75; ahora 2,50" (141, p. 14), también cuando se refiere al servicio telefónico: “el teléfono sigue costando 10 centavos de dólar (...), pero me cuesta encontrar uno sin la tira amarilla: 'Perdón, temporariamente fuera de uso"” (141, p. 14), o lo que ocurre con las entradas de teatro: "Aumento bárbaro. Antes, las musicales se veían a 9 dólares y las comedias a 5. Ahora, 15 y 10 respectivamente" (141, p. 14).

En estas crónicas, también se construye una voz cuya estrategia narrativa se aleja de la objetividad para irrumpir en lo subjetivo, para exponer un punto de vista individual a través del cruce con otros géneros y otras formas literarias como la dramatización textual. En la crónica reunida en el n. ${ }^{\circ} 141$ de Siete Días, se recrea un diálogo siguiendo la dinámica de preguntas y respuestas. En este caso, uno de los personajes indaga al otro sobre la actualidad en Nueva York, sobre el trabajo de oficina y la tensión de la vida urbana. Ese tema contrasta con las referencias al movimiento hippie y el espíritu liberal de los jóvenes en los años 60, que conduce didácticamente a una síntesis para transmitir un valor moral sin necesidad de comprometer totalmente la palabra autoral: "Estas bandadas (después del trabajo o el colegio) revolotean por Nueva York (...) y espantan del modo más directo al fantasma número uno de las grandes ciudades: la soledad" (141, p. 15), dice uno de los personajes en favor del modo de vida elegido por los jóvenes pacifistas. No obstante, este mismo gesto permite pensar estas crónicas en línea con los escritores latinoamericanos de las décadas del sesenta y setenta comprometidos en participar de algún modo en la esfera pública en la articulación de vanguardia estética y política (Bernabé, 2006, p. 12).

\footnotetext{
31 "Era cierto: G. R. no llena los zapatos (con plataforma) de Mame, y carece de personalidad escénica, pero es como visitar a una tía que cuando éramos chicos nos compraba todos los chocolatines que le pedíamos. Ginger Rogers, orgía de letras g, tía buena" (145, p. 82).
} 
El recurso de dar voz a los personajes se multiplica y llama la atención que en la crónica correspondiente al número 147, con un homenaje al director Josef von Sternberg (1894-1969) poco tiempo después de su muerte, se introducen fragmentos de diálogos de sus películas Marruecos (Morocco, 1930) y Expreso de Shangai (Shangai Express, 1932), protagonizadas por Marlene Dietrich, adelantando un recurso que introducirá en The Buenos Aires Affaire (1973). En esa novela, Puig incorpora a modo de epígrafes de cada capítulo un segmento de diálogo de películas, donde predomina la voz de la protagonista femenina, por ejemplo, de Greta Garbo en La dama de las camelias (Camille, 1937) en el capítulo uno y de Gran Hotel (Grand Hotel, 1932) en el quince, de Joan Crawford en El suplicio de una madre (Mildred Pierce, 1945) en el capítulo tres, de Bette Davies en La loba (The Little Foxes, 1941) en el once y de Rita Hayworth en Gilda (Gilda, 1946) en el dieciséis. La voz de Dietrich aparece en dos ocasiones, en el capítulo cuatro, con líneas de El expreso de Shangai, que reproducen el mismo diálogo de la crónica, aunque con algunas mínimas variantes, y en el trece con un fragmento de Fatalidad (Dishonored, 1931). Y si en la novela estas voces funcionan como una forma de recuperar y honrar a las estrellas de cine que Puig admiraba, mujeres fuertes e incapaces de pasar desapercibidas, en la crónica, reproducir un pasaje de una película del director recientemente fallecido y homenajeado es también una forma de actualizar la voz de su actriz fetiche y de acercarla al público del escritor.

\subsection{Estilo y marca de autor}

La dramatización textual que se explicaba en el apartado previo influye en la ficcionalización de los personajes que se mencionan, recurso que bucea en la experiencia con el material literario, como si el autor aprovechase todo recurso, todo momento posible para experimentar con la escritura. Esto sucede cuando, por ejemplo, en la crónica neoyorquina del número 142, le da voz a la misma Joan Crawford en la anécdota que rememora el enojo de la actriz debido al resfrío por el cual debe ser reemplazada por Katharine Hepburn:

Declaraciones de Crawford llorando en el sanatorio: "Davies ingrata no me quiere esperar. Yo la saqué del olvido. Si no hubiese sido por mí, lectora infatigable de libretos y novelas policiales, nadie hubiese descubierto Baby Jane. Yo produje el film y yo llamé a Davies. Y ahora me van a reemplazar con una de esas dos 
hermanas que siempre confundo, porque son más bien retaconas y de cabeza grande, desproporcionadas las dos" (142, p. 14).

Desde otro ángulo, la estilización literaria puede ponerse a tono con el resto del sistema de producción puiggeana, donde las descripciones de lo espectacular coinciden con la obsesión por los detalles, presentes en gran parte de su obra literaria. Cuando reseña la obra teatral “¡Oh, Calcuta!” (143), su voz se asemeja a la que funcionará en el personaje de Molina en El beso de la mujer araña (1976), con cuidado por transmitir imágenes cinestésicas concretas y en movimiento, dotadas de ritmo y energía, donde a cada objeto se le asigna un sentido que participa del conjunto de la escena, lectura de detalles que irrumpe para construir un todo kitsch, camp o hiperbólico:

Primer cuadro: penumbra, aparecen cinco mujeres y cinco hombres con ropa de calle. En el fondo del escenario se vislumbran diez perchas, y diez batas blancas. Los actores se desvisten de espaldas al público y se ponen la bata. La música es lenta y sensual, de notable delicadeza (...). En cierto momento recogen sus batas y las agitan suavemente como banderas. En ese momento nota cada uno que hay alguien a su lado. Las ondulaciones de las batas continúan pero sin tocar nunca al vecino, respetando su presencia (143). ${ }^{32}$

El cronista se detiene en todos los aspectos que construyen una imagen sensible completa, con colores, claros y oscuros, sonidos y referencias táctiles, que evidencian la capacidad memorística para captar escenas y transmitirlas, pero también para construir un cuadro de intensidad poética propia.

Otro aspecto que señala el estilo de estas crónicas es su forma de escritura fragmentaria. La percepción de la ciudad y de los espectáculos lleva a Puig a incluir lo inacabado, lo inconcluso y lo trunco en una forma de disponer la información quebrada, a la manera retazos discursivos en la focalización detallada de sucesos mínimos y detección de fracturas que irrumpen en el intento de acercarse a las cosas para dar con una versión de lo real, con el recorte de una perspectiva. Se presenta un tema en cada párrafo, seguido de dos puntos y una observación o información. Sintácticamente, esta forma prescinde en general de enlaces, y evita las formas conjugadas. Sobre este punto vale la pena mencionar que entre los borradores conservados en el archivo personal del

\footnotetext{
${ }^{32} \mathrm{En}$ El beso de la mujer araña, Molina relata un segmento de una de sus películas favoritas: "Ella baja del auto, él le besa la mano enguantada. Ella hierática, fría como un témpano. Él le pregunta si vive sola, si no tiene miedo. Ella contesta que en el fondo del jardín hay una pareja de ancianos cuidadores. Pero al darse vuelta para entrar a la casa ve una sombra en la ventana del piso alto, que desaparece inmediatamente (...). Y van al departamento de él, lujosísimo, pero muy raro, de paredes blanquísimas sin cuadros y techos muy altos, y pocos muebles, oscuros, casi como cajones así de embalaje, pero que se ve que son finísimos, y casi nada de adornos, cortinados blancos de gasa, y unas estatuas de mármol blanco, muy modernas, no estatuas griegas, con figuras de hombres como de un sueño" (2008, p. 52).
} 
escritor $^{33}$ se encuentra un folio correspondiente a un mecanograma de la crónica publicada en el número 142 de Siete Días Ilustrados, único testimonio pre-textual de todos los escritos que se analizan y que permite acceder a ciertas condiciones del contexto de producción (N.B.2.0070). En el documento, puede leerse que el autor compone inicialmente una narrativa mucho más tradicional y luego, en una segunda instancia, corta las frases y estructura su escrito en consignas breves y disparadoras de ideas que fragmentan el discurso, un movimiento coincidente con el que se ha observado para la novela Boquitas pintadas (Rodas, 2015), cuyo proceso de reelaboración también experimenta distintas posibilidades de la lengua literaria. En el caso de la crónica, esto ocurre, ya que si en el mecanograma (N.B.2.0070) inscribe la frase: "La alquimia de estrellas funcionó y el nombre de Katharine se actualizó despegándose al mismo tiempo del de Spencer Tracy”, en la publicación de la revista se lee: “Alquimia de estrellas: funciona, y el nombre de K. H. se actualiza, despegándose del de Spencer Tracy” (142, p. 14). Las transformaciones operadas en el proceso de escritura como la eliminación del artículo en la frase transformada en subtítulo seguida de dos puntos ("Alquimia de estrellas:"), la actualización del tiempo verbal en el intercambio del pretérito por el presente ("funcionó" y "se actualizó" por "funciona" y "se actualiza") y la omisión de la frase temporal ("al mismo tiempo") dan forma a un texto más fragmentario que requiere una atención capaz de reponer las informaciones que el texto omite en un juego interpretativo del que el lector es parte fundamental. Estas operaciones, de un modo similar al que Julio Ramos (2003, p. 110) ha notado para el caso de José Martí, subvierten la lógica del discurso periodístico que basa su valor en la transparencia del lenguaje en un gesto de experimentación formal con la lengua literaria, todas formas discursivas y recursos que el escritor explota en el conjunto de su obra y que en esta instancia se esfuerza por dar a conocer a sus lectores de revista.

\footnotetext{
${ }^{33} \mathrm{El}$ archivo de Manuel Puig está a cargo de su hermano, el señor Carlos Puig y de Mara Puig, sobrina del escritor. Agradezco su amabilidad por permitirme consultar los papeles personales del escritor.
} 


\section{Reflexiones finales}

Las cuestiones expuestas en los apartados previos son vitales para la consideración de la crónica como intermediaria entre el discurso literario y el periodístico, y con otras formas híbridas como el epistolar, pero en definitiva como un género en el cual es posible reconocer un estilo y subjetividad del escritor. En el caso estudiado, sirve a la autoafirmación y el reconocimiento de las marcas de escritura de un autor como Manuel Puig, lanzado al éxito con Boquitas Pintadas, y afianzado en el trayecto profesional que inicia con su primera novela, La traición de Rita Hayworth, donde inaugura una búsqueda literaria de experimentación y vanguardia.

Se ha puesto en evidencia el aporte de lo masivo en la consagración de este autor que se adapta al circuito de revistas de actualidad en las que participa. En esos medios, se destaca la relevancia dada a su nombre no solo en las tipografías de gran tamaño que lo anuncian, y denuncian su definitiva profesionalización y aceptación, tanto de la crítica como del público general, sino también, y mucho más importante, en el trazo de su propia mano como sello y seña de un estilo que ha sido asumido y que se reproduce en la forma de un cuerpo y de una voz que lo (re)presentan y hablan por él. Complementariamente, la lectura en la página establece, como es común en el discurso de la prensa, un juego complementario de envíos y reenvíos entre las imágenes, los epígrafes, los destacados y el cuerpo textual que orientan la recepción y la lectura siendo redundantes, en este caso, en los eventos espectaculares y en la vida común, objeto de las críticas de Puig, pero también en un tono familiar con toques de humor que busca empatizar y atraer a su lector.

En cuanto a las particularidades de estilo, la redundancia en el recorte del punto de vista, de lo fragmentario e inconcluso, insiste en una poética escrituraria que se niega a la autoridad monocorde de una voz homogénea y transita los espacios oscilantes entre la voz del crítico teatral, del ensayista o del observador que transmite con precisión los detalles mínimos de aquello que causa admiración o interés singular, en especial por la espectacularidad del evento. A ello se suma el interés por señalar el quiebre con el tiempo presente y la nostalgia de un tiempo que fue concurrente con el recurso de dar la palabra a las protagonistas de las obras que ve para darles vida y recuperar del pasado a las glorias del cine clásico, musas que pueblan la literatura puiggeana.

Resta decir que estas conclusiones abren la puerta a nuevas preguntas sobre el rol de Puig como cronista para indagar con mayor detalle su relación con cada una de las 
ciudades que visita en articulación con distintos momentos de su carrera, así como también su intervención como escritor-periodista en otros medios masivos, temas que no escapan a nuestro interés en futuras investigaciones.

\section{Bibliografía}

Barthes, Roland. (2012). Fotogenia electoral. En Mitologías (pp. 166-168). Bs. As.: Siglo Veintiuno.

Bernabé, Mónica. (2006). Prólogo. En María Sonia Cristoff y Rosario Beatriz Viterbo (Eds.), Idea crónica: literatura de no ficción iberoamericana (pp. , 7-25). Buenos Aires: Fundación Typa.

Bocchino, Adriana. (2006). Notas sueltas entre los papeles de Manuel Puig. En José Miguel Onaindia (Ed.), Manuel Puig presenta (pp. 46-49). Buenos Aires: Fundación Internacional Argentina.

Bowers, Fredson. (1949). Principles of Bibliographical Description. Princeton: U.P.

Bouvet, Nora. (2006). La escritura epistolar. Buenos Aires: Eudeba.

Caparrós, Martín. (2007). Por la crónica. Recuperado de http://congresosdelalengua.es/cartagena/ponencias/seccion_1/13/caparros_marti n.htm

Cingolani, Gastón. (2009). Tapas de semanarios argentinos en el siglo XX: historia discursiva de un dispositivo y dos medios. Figuraciones, (n. ${ }^{\circ}$ 5, agosto). Recuperado

de http://www.revistafiguraciones.com.ar/numeroactual/articulo.php?ida=100\&idn $=5 \& \operatorname{arch}=1 \#$ texto

Fernandez, Cristina Beatriz (Ed.). (2009). Nota preliminar. En Las crónicas de José Ingenieros en La Nación de Buenos Aires (1905-1906) (pp. 7-11). Mar del Plata: Martín.

Garsar, Alberto. (1971). Conversación con Manuel Puig. Femirama, IX(julio), 38-44. Gaskell, Philip. (1999). Nueva introducción a la bibliografía material. Asturias: Trea. 
Giordano, Alberto. (2001). La conversación infinita. Rosario: Beatriz Viterbo.

Giordano, Alberto. (2006). Sueño querido. Las cartas europeas de Manuel Puig (19561962). En Una posibilidad de vida. Escrituras íntimas. Rosario: Beatriz Viterbo.

Goldchuck, Graciela. (2006). El legado banal. Una lectura genetista de la relación entre cine y literatura en los textos de Manuel Puig. En José Miguel Onaindia (Ed.), Manuel Puig presenta (pp. 73-87). Buenos Aires: Fundación Internacional Argentina.

Goloboff, Mario. (1997). “El camino de la oralidad”. En José Amícola y Graciela Speranza (Eds.), Encuentro Internacional Manuel Puig (pp. 70-76). Rosario: Beatriz Viterbo.

Idez, Ariel. (2009). "Manuel Puig: la traición del cronista". XII Jornadas Nacionales de Investigadores en Comunicación. "Itinerarios de la comunicación. ¿Una construcción posible?”. San Luis, Argentina. Recuperado de http://www.redcomunicacion.org/memorias/p_jornadas_p.php?id=1031\&idj=10

Jill Levine, Suzanne. (2002). Manuel Puig y la mujer araña. Su vida y ficciones. Buenos Aires: Planeta/ Seix Barral.

Laera, Alejandra. (2007). "Un hombre de mundo". En Manuel Mujica Láinez. El arte de viajar. Antología de crónicas periodísticas (1935-1977) (pp. 11-36). Bs. As.: Fondo de Cultura Económica.

Laufer, Roger. (1972). Introduction à la textologie. Vérification, établissement, édition des textes. Paris: Larousse Université.

McKenzie, Donald Francis. (2005). El libro como forma expresiva. En Fernando Bouza (Trad.), Bibliografía y sociología de los textos. (pp. 27-47). Madrid: Akal.

Páez, Roxana. (1995). El sexo punk. En Manuel Puig. Del pop a la extrañeza (pp. 139147). Buenos Aires: Almagesto.

Pauls, Alan. (1986). Manuel Puig: La traición de Rita Hayworth. Buenos Aires: Hachette.

Plager, Federico (coord.). (2008). "Bochorno". "Colorinche”. "Mersa". Diccionario integral del español en la Argentina. Buenos Aires: Voz Activa.

Puig, Manuel. (1968). La traición de Rita Hayworth. Buenos Aires: Jorge Álvarez. 
Puig, Manuel. (1969). Boquitas pintadas. Folletín. Buenos Aires: Sudamericana.

Puig, Manuel. (1973). The Buenos Aires Affaire. Buenos Aires: Sudamericana.

Puig, Manuel. (1985). La cara del villano y Recuerdo de Tijuana. Barcelona: Seix Barral.

Puig, Manuel. (1993). Estertores de una década. Nueva York '78. Barcelona: Seix Barral.

Puig, Manuel. (2013). Estertores de una década. Nueva York '78. Buenos Aires: Booket.

Puig, Manuel. (2005). Querida familia: Tomo 1. Cartas europeas. (1956-1962). Graciela Goldchluk (Ed.). Buenos Aires: Entropía.

Puig, Manuel. (2006). Querida familia: Tomo 2. Cartas americanas. New York-Río (1963-1983). Graciela Goldchluk (Ed.). Buenos Aires: Entropía.

Ramos, Julio. (2003). Desencuentros de la modernidad en América Latina. Literatura y política en el siglo XIX. México, D. F.: Fondo de Cultura Económica.

Reguillo, Rossana. (2007). Textos fronterizos. La crónica una escritura a la intemperie. En Graciela Falbo (Ed.), Tras las huellas de una escritura en tránsito. La crónica contemporánea en América Latina (pp. 41-50). La Plata: Al margen.

Rodas, Giselle. (28, 29 y 30 de octubre de 2009). Boquitas pintadas. Folletín: un recorrido por las publicaciones de la novela en Argentina y España. Actas del II Congreso Internacional "Cuestiones Críticas". Facultad de Humanidades y Artes, Universidad Nacional de Rosario. Recuperado de http://www.celarg.org/int/arch_publi/rodas.pdf

Rodas, Giselle. (Inédito). Edición crítico-genética de Boquitas pintadas: Folletín (1969) de Manuel Puig (Tesis doctoral, fecha de defensa: junio de 2015). Universidad Nacional de La Plata. Facultad de Humanidades y Ciencias de la Educación.

Rotker, Susana (2005). La invención de la crónica. México D. F.: Fondo de Cultura Económica.

Sarlo, Beatriz. (1992). Intelectuales y revistas: razones de una práctica. Le discours culturel dans les revues latino-américaines (1940-1970), (9/ 10), 9-16.

Siete Días Ilustrados. (1970). N. ${ }^{\circ} 140,12$ al 18 de enero.

Siete Días Ilustrados. (1970). N. ${ }^{\circ} 141,19$ al 25 de enero.

Siete Días Ilustrados. (1970). N. ${ }^{\circ} 142,26$ de enero al $1 .^{\circ}$ de febrero. 
Siete Días Ilustrados. (1970). N. ${ }^{\circ} 143,2$ al 8 de febrero.

Siete Días Ilustrados. (1970). N. ${ }^{\circ}$ 144, 9 al 15 de febrero.

Siete Días Ilustrados. (1970). N. ${ }^{\circ} 145,16$ al 22 de febrero.

Siete Días Ilustrados. (1970). N. ${ }^{\circ} 146,23$ de febrero al $1 .^{\circ}$ de marzo.

Siete Días Ilustrados. (1970). N. ${ }^{\circ} 147,2$ al 8 de marzo.

Siete Días Ilustrados. (1970). N. ${ }^{\circ}$ 148, 9 al 15 de marzo.

Sosnowski, Saúl. (1973). Manuel Puig: entrevista. Hispamérica: Revista de Literatura, 3, 69-80.

Ulanovsky, Carlos. (2005a). Paren las rotativas (1920-1969). Buenos Aires, Emecé.

Ulanovsky, Carlos. (2005b). Paren las rotativas (1970-2000). Buenos Aires, Emecé.

Ulanovsky, Lucía. (2009). Fotografía de prensa y el Cordobazo. Entre tradición y modernización de los tratamientos fotográficos. Revista Chilena de Antropología Visual, (diciembre), 42-66.

Van Dijk, Teun A. (1998). La ciencia del texto. Sibila Hunzinger (Trad.). Buenos Aires: Paidós.

\section{@) $\odot \Theta \Theta$}

Esta obra está bajo una licencia de Creative Commons Reconocimiento-NoComercial- 